\title{
"Young Phoenicians" and the Quest for a Lebanese Language: between Lebanonism, Phoenicianism, and Arabism
}

\author{
Franck Salameh
}

In the context of modern Middle Eastern history, the varied peoples of the "Greater Middle East" are often viewed through simplified notions of "Arab" and "Muslim," sometimes to the neglect of other, pre-Arab pre-Muslim Middle Easterners otherwise lapsed from the prevalent paradigms on, of, and about the modern Middle East. To non-historians, a century or more of Western academic interest in the region seems to have yielded little beyond clichés and assumptions referring to “'Arabs,' 'Arab' fears, 'Arab' hopes, 'Arab' concerns, and 'Arab' hang-ups - 'Arab' being the emblematic "be all end all” of all matters Middle East."' Yet there exists a vibrant and venerable Middle East outside the dominant platitudes about which traditional Middle East scholarship remains largely mute. It is within this context that this paper offers the suggestion that the prevalent assumptions about an essentially Arab (or uniformly Muslim) Middle East be confronted with a more culturally and religiously diverse Middle East. In line with this, this paper focuses on the so-called "Young Phoenicians" in Lebanon who in the early twentieth century put forward another interpretation of the history of the region and of their region, foregrounding non-Arab and non-Muslim interpretations of it.

In Lebanon, the tendency towards valorising and celebrating the longue durée of Middle Eastern history and memory is referred to by the generic term 'Phoenicianism'. For obvious reasons, from the perspective of the keepers of Arabist orthodoxy Phoenicianism is deemed problematic, because it relegates "Arabness" to a period - rather than an essence - of Lebanese history.

1 Elie Kedourie, "Not So Grand Illusions," New York Review of Books 9,9 (Nov. 23, 1967). No page number. 
Yet Phoenicianism is also a canonical, long-standing school of thought that resonates among large swaths of a Lebanese society not always enthralled with the assumptions of Arab nationalism. The current was elaborated by an early twentieth-century group of young Francophone philo-Phoenicians - mainly Lebanese Christians - who went by the sobriquet Les Jeunes Phéniciens - the "Young Phoenicians." In short, these latter-day Canaanites viewed themselves and the modern Lebanese as a singular, unique group, descendants of the Canaanite seafarers of antiquity (not the newly arrived Arab conquerors). From their perspective, they and their Phoenician ancestors were exemplars of humanism, at once skilled traders, intrepid mariners, subtle disseminators of knowledge, gifted cultural intermediaries, and fluid congenital polyglots straddling multiple traditions, multiple languages, and multiple cultural legacies.

An eminent "graduate" of the Young Phoenicians' intellectual circle, Michel Chiha (1891-1954), co-author of the 1926 Lebanese Constitution and a proponent of multiple identities, described the modern Lebanon of the "Young Phoenicians" as a diverse, multiform, polyglot cocktail of cultures and languages. His was a conception of identity that valued composite, complex patchworks of ethnicities and historical memories; a millennial universe of varied civilizations, where peoples and times blended without dissolving each other, and where languages, histories and cultures fused without getting confused with one another. Lebanon of the Phoenicians, Chiha wrote,

is a meeting place into which peoples flock and assimilate regardless of their origins. Lebanon is the preeminent crossroads where varied civilizations drop in on one another, and where bevies of beliefs, languages, and cultural rituals salute each other in solemn veneration. Lebanon is above all a Mediterranean construct, but like the Mediterranean itself, Lebanon is a nation discerning and sensitive to the stirring music of universal poetry. ${ }^{3}$

This sort of discourse was part and parcel of Chiha's worldview. It is an important element of his political writings, his journalistic output, and his public speaking engagements in various Beirut forums - such as the Cercle de la

2 Franck Salameh, Language Memory and Identity in the Middle East; The Case for Lebanon (Lanham, MD: Lexington Books, 2010), 45.

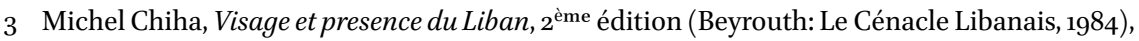
49. All translations from Arabic and French originals are the author's own. 
jeunesse Catholique (1929) and the Cénacle libanais (1946). There, Lebanese beholden to the creed of Arab nationalism often met their match in Lebanese Phoenicianists who, like Chiha, "thought of their country as a piece of Europe, at the foot of a splendid mountain, [savouring] the language of France."4 Like his "Young Phoenician" cohorts, Chiha recognized the Arabs' and Muslims' presence in Lebanon (and the Middle East as a whole) as a matter of fact, as a cycle in the chronology of peoples and conquerors that took possession of the Middle East at a given time in its history. But Chiha stressed that a mere thirteen centuries of Arab and Muslim domination,

were not nearly enough to make the people of Lebanon oblivious to, or dismissive of, the fifty centuries that preceded the Arabs!-[...] Even if relying entirely on conjecture, the blood, the civilization, and the language of today's Lebanese cannot possibly be anything if not the legacy, the synthesis, and the sum of fifty centuries of progenitors and ancestors. ${ }^{5}$

From Chiha's perspective the importance of the Young Phoenicians stemmed from their remarkable humanistic, elastic (spacious) conception of history and memory. Admittedly, this conception while opposed to essentialist Arab and Muslim interpretations, did not disown the Arabs, did not bespeak hang-ups regarding Muslims, and did not shun the rich Muslim/Arab cultural, linguistic, and literary patrimony - which the Young Phoenicians deemed an important (albeit lone) piece in a larger patchwork rather than a dominant motif. Indeed, Chiha and the Young Phoenicians were passionate about the preservation of the Arabic language in the pantheon of Lebanese polyglossia, which, from their perspective, constituted a splendid addition to Lebanon's vaunted cosmopolitanism and linguistic humanism. What they repudiated, however, were linguistic dogmatism, national rigidity, and cultural coercion and regimentation. Arabic is a wonderful language, Michel Chiha stressed:

It is the language of millions of men. We wouldn't be who we are today if we, the Lebanese of the twentieth century, were to forgo the prospects of becoming the Arabic language's most accomplished masters to the same extent that we had been its masters some one hundred years ago ... How can one not heed the reality that a country such as ours would be

4 Marius Deeb, Syria, Iran, and Hezbollah: The Unholy Alliance and its War on Lebanon (Stanford, California: The Hoover Institution Press, 2013), xiv-xv.

5 Michel Chiha, Le Liban d'Aujourd'hui (1942) (Beyrouth: Editions du Trident, 1961), 49-52. 
literally decapitated if prevented from being bilingual (or even trilingual if possible)? ... [We must] retain this lesson if we are intent on protecting ourselves from spiteful [monolingual] nationalism and its inherent selfinflicted deafness [to other languages]; an affliction that may lead us to assured cultural mutism. ${ }^{6}$

There is arguably no more exquisite a celebration of cosmopolitanism, and no more forceful a rejection of nationalist jingoism than this text. Chiha, as a representative of the Young Phoenicians, certainly did not shun the Arabic language or its cultural trappings. Yet he remained uncompromising in his rejection of Arab nationalist linguistic authoritarianism and the cultural conformity that it demanded.

Charles Corm (1894-1963), poet laureate and éminence grise behind the Young Phoenicians, described his ancient ancestors' and modern compatriots' cultural and linguistic 'pantheism' as the founding elements of human civilization, at once human, humane, and humanistic, selflessly bestowing gifts through both time and space upon all peoples of the globe. ${ }^{7}$ This worldview of Corm's - an element of the kind of benevolent nationalism that he advocated - would attain its finest incarnation in an address that he gave in Beirut in June 1949, at a meeting of the Cénacle libanais. In this, Corm noted that since the remotest antiquity, at a time when they were still known as Canaanites,

and later as Phoenicians, the Lebanese had created, preserved, defended, affirmed and advanced an expansive and liberal civilization with universal impulses and qualities so accessible to other peoples that some of those, even the loftiest and brightest among them, came to assimilate these attributes of Lebanese civilization as if they were their own, identifying them with their own national genius. ${ }^{8}$

6 Chiha, Visage et presence, 49-52, 164.

7 Charles Corm, "Déclaration de M. Ch. Corm," Les Principes d'un Humanisme Méditerranéen (Monaco, November 1935), 25.

8 Corm, "Déclaration de M. Ch. Corm," 25. 
This, in Corm's view, was the incarnation of humanism. And in that sense, Lebanon was not only a most exquisite practitioner of humanism, but also an eloquent purveyor of that most human of human virtues, contributing to the "building of a better human community, and a more humane humanity."

Although advocating - and indeed living - polyglossia as a defining element of Lebanese specificity and its Phoenician filiation, the Young Phoenicians' main linguistic-intellectual media remained French - and in certain iterations Arabic. They used French to escape the Arabic language and the stigma of 'Arabness' that is often attached to it. ${ }^{10}$ They also used Arabic in order to prove their detractors wrong: to affirm their proficiency in Arabic (alongside other languages,) and to stress that just like Irishmen, Scotsmen, Liberians, Nigerians and others who may be native Anglophones but not Englishmen, so could Lebanese be the avant-garde of Arabic linguistic revival and Arabic belles lettres, and yet remain distinctly Lebanese. However, there remained an impulse for 'authenticity' that continued to animate the Young Phoenicians movement, an impulse which, although using the French and Arabic languages, often with the intimacy and alacrity of natives, still yearned for an 'authentic' Lebanese language. This tendency followed two paths: one attempted to revive Syriac and Canaanite as the autochthonous, authentic, unique languages of Lebanon (Bnay Qyomo is a modern current endorsing and promoting this ongoing project); ${ }^{11}$ on the second path these revival movements were dismissed as futile and counterintuitive, with the argument that an authentic Lebanese language already existed, and that the Phoenician language and its Syriac iterations were already living presences, transmuted into the modern spoken Lebanese vernacular. ${ }^{12}$ In other words, as the argument went, the spoken vernaculars of modern Lebanon, as they had always been, were not "defective

9 Corm, "Déclaration de M. Ch. Corm," 24.

10 Throughout its modern history, Lebanese Arabists who saw the country's cultural accretions as corollaries of Arab-Muslim history used Modern Standard Arabic as their political and literary medium. Conversely, those Lebanese who saw their identity to be the outcome of a pre-Arab - i.e., Phoenician - progenitor were largely, albeit not exclusively, francophone.

11 See for instance the following websites related to the Bnay Qyomo: https://www.youtube .com/watch?v=IVrnWRDVLqk; https://www.youtube.com/watch?v=fappJX7DX6U; https:// www.facebook.com/BnayQyomo/posts/1679274845681410; https://www.youtube.com/ watch?v=wFzFwKhLzrU.

12 See for instance Fouad Ephrem Boustany's “La trace du Phénicien Ugaritique dans le parler Libanais" in Opera Minora; Studia Libanica (Beirut: Editions ad-Da'irah, 1986), 69-87. 
Arabic dialects," but indeed "evolved Phoenician dialects." ${ }^{3}$ Thus, instead of 'revival' this last group advocated the "codification" of this "Lebanese language" in written form, in a modern incarnation of the Phoenician alphabet, as embodied in the Roman characters. Both these tendencies were born in the early 1920s; they co-existed with the establishment of Greater Lebanon and the birth of the Young Phoenicians movement. And although both became a reality benefitting from a coherent programme only in the middle of the 1950s - with the "codification" track triggering a 'dialectal' and literary revival - the idea of a distinct, ageless, enduring "Lebanese language" was the brainchild of Young Phoenician poet laureate Charles Corm himself. Although not a linguist, Corm wrote with the keen discernment of one, maintaining that, its hybridity notwithstanding, Lebanese was synchronically speaking a distinct language in its own right, deserving recognition and valorisation as such. By the early 1930 se was already advocating his "Lebanese language," in French.

In his 1934 Phoenicianist manifesto, the monumental La Montagne Inspirée ("The Hallowed Mountain"), Corm charted the rehabilitation and redemption of what he called "ma langue libanaise," "my Lebanese language," describing it "lyrically," but addressing it like a living being. "No, no, my mother tongue," came Corm's invocation:

You aren't a fallen corpse in the abyss of time! / For, I still can feel your verve, swelling up in my veins, / Rising up like springtide, surging up like a wave! / And I still can hear, your sparkling silver springs, / Churning up from the past, whispering to my soul ... / ... Your soft and graceful inflexions, still slip their ancient drawl, in all the modern languages, swarming on our shores; / Your sparse and scattered caresses, still flow in my veins, and cuddle with my soul!! / ... For, even as I write, in someone else's

13 For instance, Lebanese poet and language reformer Saïd Akl (1912-2014,) a friend and mentee of Charles Corm and Michel Chiha, claimed "spoken Lebanese" to be a language sui generis - a Semitic language to be sure, but a distinct language - that is not an offspring of Arabic. The "Lebanese language," Akl argued, "can best be described as the sum of centuries of a congenital bilingualism and a natural confluence between Canaanite, Aramaic, Latin languages, Arabic dialects, and Turkish." Certain syntactic peculiarities of Lebanese, he noted, "are clearly Phoenician and Aramaic, while the lexicon may also draw heavily on Arabic, Latin, French, or Turkish." And so, stressed Akl, "the Lebanese language is not some vulgar form of an eloquent and arcane Arabic [...]; it is an indigenous and spontaneous outcome of a uniquely Lebanese experience [...], and it has always been the native spoken language of the Lebanese people." It has certainly been transformed over the millennia, he admitted, to reach the modern spoken form under which it is found today; but it remains "an evolved form of Phoenician, not a vulgar or colloquial Arabic." (see for instance "Netruk Ba'a l-Arabi" [Enough Already with the Arabic Language], Lebnan, (Beirut: Volume IX, Number 433, Friday August 10, 1984), 1. 
language, and even when I speak, in someone else's tongue, / It's still you in my voice, My sainted Mother's voice, / Snug like a lover's warmth! / For, Man here below, in spite of having learnt, his brute oppressor's tongue, / Has kept the looks the tone, Has kept the pitch, the pulse, / Of his forefather's inflections, of his ancient mother's voice! / ... For, even these sweet words, stolen from France's lips, / With impassioned affection, quivering in my heart, / Still taste on my lips, where my smiling sorrow sits, / Still taste of a Lebanese kiss. ${ }^{14}$

And so, even in lamentation, it seems Corm recognized a hidden vigour to his ancestral tongue, a living artefact which he claimed had fused with and were infused in the modern languages currently spoken in Lebanon. In Corm's telling, a national language was like a timeless, warm, hallowed maternal voice, emanating from a distant past, reverberating in the present, emitting shudders of national pride and tales of forebears and glory. Therefore, even when they seemed to acquiesce in - even boasting of - their congenital polyglossia, the Young Phoenicians of Corm's generation still yearned for an 'authentic' national language and recognized the endurance and latent essence of this 'national language' in their modern idioms. The multilingualism flaunted in Lebanon was, in Corm's words, simply a palliative, a borrowed outer garment, an artifice meant to ward off the dominance of any single "intruder" language. Yet, the "Lebanese language" that he spoke of - both an 'internal' emotive language and an actual living competency - impregnated, metabolized, and transmuted the other idioms currently in use: i.e., Arabic, which, like other languages, Corm viewed as an intruder on pre-existing unique speech forms.

What is worth noting is that although written in French, and in the French mediaeval poetic tradition of the chanson de geste chronicling local heroic exploits, La Montagne Inspirée was, as stated by Corm, "traduit du Libanais" that is to say "translated from the Lebanese language." Indeed, the introduction to each of the poem's three "cycles" (or narrative "sagas") presented these as French renditions of an original Lebanese poem, thus suggesting that although "speaking in tongues" as it were, and sounding French, Italian, or for that matter Arabic, the linguistic reservoir of the modern Lebanese people remained a single authentic ancestral "Lebanese" language, a bequest of the ancient Phoenician progenitor. To wit, in his Hallowed Mountain's "Saga of Memories" Corm affectionately noted how his own grand-parents spoke Syriac - not Arabic - in late-nineteenth century Lebanon, and that this same Syriac, a relic

14 Charles Corm, La Montagne Inspirée (Beirut: Éditions de la Revue Phénicienne, 1934/1987), $105^{-6 .}$ 
of Phoenician, remains the language of Lebanon to this day. 15 "Grief, good grief, O unspeakable grief," he wrote,

My own grandparents spoke, Syriac in Ghazir. / Syriac, where the Phoenicians' flair, their vigour and their flame, are still extant today; / Alas, no one now can fancy finding shades / Of our grandparents' footsteps, in the shadow of ancient vines; / The bygone language of yore, is choked for evermore, in our scrawny muzzled throats. / And now our Mountain, Ever kind to her sons, / Beholds its splintering skies, riven by the sounds, of foreign Western tongues; / [...] For, languages like Italian, like English and Greek, / Like Turkish and Armenian, clutter and jam her voice, / While she willingly yields to the sweet tyranny of the language of France. / Yet, I know that in London, In Paris and in Rome, / Our writers can never hold the station they deserve, / That everywhere they go, despite their humanity, / They shall always remain, outside the human race. / For, a people is orphaned when it hasn't a tongue; / And the languages of others are borrowed outer cloaks, / In which one seems dubious, shameful, lifeless, frail, obnoxious and strange! / [...] Yet, these foreign-sounding words, which are taught to our children, / To us are not that strange; / For, it seems that our hearts can still recall remembrances, of having fashioned them, and styled their graceful sounds! / Indeed, it is they, who

15 It is not within the scope of this paper, and neither is it my intent, to prove or disprove the veracity of Charles Corm's claim. Many Lebanese Maronites of Corm's grandparents' generation, into the mid- to late- nineteenth century, did indeed cling to remnants of Syriac even if only for liturgical and ceremonial purposes. However, the focus here is purely on the context of ideas and intellectual history: the fact that such a claim was indeed made (and continues to be made) in modern Lebanon, and why. Thus, what concerns me are the socio-political and intellectual impulses behind such claims rather than their "linguistic" credibility or historical accuracy. Corm is obviously appealing to an "internal" language here; an emotive affective amulet with which he seeks to "resurrect" his "ancestral tongue," even if only as a lyrical pursuit to satisfy personal (or patriotic/nationalist) yearnings for the "language of the Phoenicians." The fact that he prefaces each "saga" in his poem with the phrase traduit du Libanais (or "translated from the Lebanese language") speaks precisely to the "soul," the "inspiration," or the "internal language" behind the poems; these are all sentiments that remain fundamentally Lebanese in Corm's telling. Therefore, although Corm uses all the languages of mankind, often with the intimacy and alacrity of natives - as is the case with Corm's French language here - the Lebanese of Corm's persuasion (and generation) still breathed, clasped, sensed, and spoke a distinctly unique Lebanese language.-And so, Corm's "symphonic epopee" ends with the disclosure that "even these sweet words, / Stolen from France's lips, / With impassioned affection / Quivering in my heart, / They still taste on my lips, / Where my smiling sorrow sits, / Still taste of a Lebanese kiss." 
disowned their lineage; / Uprooted from us, torn from our embrace, / Embellished by exile, like beloved ingrates, they now disown their race. ${ }^{16}$

And so, following a drawn-out lamentation over Lebanon's ostensible loss of its "authentic, native" language - be it Phoenician or Syriac-Aramaic - Corm concludes on a note of exuberant optimism, affirming that Phoenician-Syriac, that is to say a unique Lebanese language, "is alive and well and vibrant and living out-loud" in his Lebanon. Again, this alludes to the axiom of Corm's times' that synchronically speaking, and notwithstanding its mingling of Aramaic syntactic constructions with Arabic morphology, Lebanese is indeed a distinct language in its own right. ${ }^{17}$ Yet, Corm's resonance and the impact of his work dwelt more in the realm of the cultural, the affective, and the symbolic, rather than the measurable and the purely linguistic. Ironically - and although cultural specificities ought to be evaluated not by way of genetic information but rather through historical accretions - recent studies have demonstrated that the Lebanese of today and the Phoenicians of classical antiquity share with each other some $90 \%$ of their genetic lineage, thus validating by science what Corm already knew in his heart. ${ }^{18}$

Thus, as time moves ever further away from the day La Montagne Inspirée was first published, wrote Élie Tyane in 1935, and as the tempests that had vigorously shaken the souls of those who came into contact with those sublime verses in 1934, Charles Corm's Hallowed Mountain goes on acquiring new meanings and added gravitas. ${ }^{19}$ The poem is not only an "ode" to Lebanon's ancient glories and an optimist vision of its days to come, but also, as Tyane argued, was above all a confirmation of Lebanon's high moral values and a restitution of the country and its people to their true selves and their true history. "Long had I stayed in awe of this book," Tyane wrote,

unable to write or utter a single commentary on it, crushed and eclipsed as I was by the enormity and loftiness of the emotions taking hold of me as I ran through its pages, breathless, thunderstruck, euphoric. Today,

16 Corm, La Montagne Inspirée, 101-2.

17 Boustany, "La trace du Phénicien Ugaritique," 70.

18 Pierre A. Zalloua et al., "Identifying Genetic Traces of Historical Expansions: Phoenician Footprints in the Mediterranean," American Journal of Human Genetics 83, 5 (2008). https://www.ncbi.nlm.nih.gov/pubmed/18976729. See also Ornella Antar's "Depuis des millénaires le peuple libanais n'a pas bougé d'un iota" in L'Orient Le Jour, Beirut, July 29, 2017. https://www.lorientlejour.com/article/1064754/-depuis-des-millenaires-le-peuple -libanais-na-pas-bouge-dun-iota-.html.

19 Élie Tyane, Lumière sur la Montagne (Beirut: Éditions de la Revue Phénicienne, 1935), 7. 
however, with my soul finally composed, reasonably collected before the hallowed image that La Montagne Inspirée evokes, I feel myself ready to bear witness, not so much to the inherent beauty of this work, as to the filial piety that it exuded, conferring upon it an almost sacred aura. ${ }^{20}$

But Tyane's wonderment at the exalted lyricism (and realism) of The Hallowed Mountain was not an exception; it had become the prevailing emotion with most of those who came into contact with that epochal work. An energizing blast of energy and warmth "reminiscent of a Victor Hugo and an Alphonse de Lamartine" runs through the pages of La Montagne Inspirée, boasted a 1934 editorial in Lebanon's leading French-language journal, La Revue du Liban. ${ }^{21}$ Reading Charles Corm, La Revue wrote, one feels as if possessed, inflamed, entranced, and carried away on a breath-taking journey through the millennia, breathing love and nostalgia. Like many other Lebanese poets, Charles Corm drew divine inspiration from Lebanon's mountains; yet, he remained so different from all those who came before him, and possibly all those who may follow, because,

nowhere, at any time in its history, has Lebanon been graced with a moving, tormented, passionate national cantor such as Charles Corm, and nowhere have we heard in Lebanon national inflections as vibrant and as powerful as Charles Corm's! The Hallowed Mountain is truly a landmark of our literary history [...] worthy of the widest audiences possible. Indeed, one feels it is the duty of the Lebanese government to disseminate this work and make it required reading in Lebanon's national schools. ${ }^{22}$

In many ways, La Montagne Inspirée was a book that strictly speaking went way beyond the realm of poetry and memory, wrote one reviewer in 1935; "it is a manifesto! A summons to Lebanese youth" and an exhortation for them to draw faith, hope and energy from the living fountainhead of their proud lineage. ${ }^{23}$ Even the Anglophone press of the times had its say, with a review in Domestic and Foreign Research of November 1934 hailing La Montagne Inspirée as a "remarkable poetic composition of stirring religious strains [...]; an Epopoeia of sublimely inspired lyricism, setting forth the contributions of Phoenicia

20 Tyane, 8.

21 See E.M., “La Revue du Liban et de l'Orient Méditerranéen," Paris, February 1934, in Extraits de la Critique (Beirut: Éditions de la Revue Phénicienne, 1935), 3.

22 E.M., "La Revue du Liban," 3-4.

23 Jeanne Archache, "La Bourse Egyptienne," Alexandria, February 8, 1935, in Extraits de la Critique, 6. 
to this world civilization, from the remotest times to our days." ${ }^{24}$ In this same vein, Eliahu Epstein's editorial in the Palestine Post of February 24, 1935, entitled "Lebanese Renaissance," perhaps merits being reproduced in its quasi entirety here. Not only because it concisely encapsulated Charles Corm's thought, but also because it spoke to the intimacy with which Epstein himself understood Charles Corm - and indeed the intellectual bond that the two of them shared. "La Montagne Inspirée' is more than a mere collection of poems," wrote Epstein:

It is an enthusiastic expression of an "idée mystique" of the author, the idea of Lebanese renaissance. Charles Corm is a Lebanese patriot who preaches all through the pages the revival of the old Phoenician civilization. His dreams are like those of Astarte and Baal. His heroes are Hiram, Fakreddin, Emir Bechir, Youssef Karam, the emigrants and the peasants of the mountain. He is inspired by Byblos and by Ras Shamrah who speak to his mind and heart, in a more compelling voice than the cultures under which the Lebanese lived and developed since Phoenician days. Lebanon to him is not merely a part of the Arab world. He speaks of the Lebanese tongue, which is the old Phoenician. He speaks of "our leaders" which to him are not the present leaders, but the heroes of old, to whom he would like to hark back, for the revival of that brilliant age which made Lebanon a power in the world, and his ancestors were the bearers of culture; when Tyre and Sidon, and Byblos were metropolises from which emanated knowledge and learning to the far-flung corners of the world. Corm is not a new name: he is the director of the Revue Phénicienne, one of the founders of the Association des Gens de Lettres of Beirut, and the promoter of Les Auteurs Libanais de Langue Française. There can be but little doubt that one of the factors which inspired the new Phoenician aspirations was the Zionist movement which has encouraged them to dream of reviving their own culture and traditions. Corm writes prose and poems. They are a mixture of the epic, sometimes weaved into lyric emotions. He recalls the greatness of the old Phoenicians whose Kings built the garden of Semiramis and the temples of the Near East; of the Phoenician colonies in Africa. Has the greatness of the Phoenicians been dimmed, he asks, because they were merchants and sometimes forgot that independence must be defended even by blood? We may expect more from the

24 Charrier, "Domestic and Foreign Research," New York, November 25, 1934, in Extraits de la Critique, 4 . 
pen of Charles Corm. He is not only an able poet, but a man who battles for his ideas. ${ }^{25}$

Even those Lebanese not particularly enthralled with Charles Corm's Phoenicianist affections could not help being charmed by the imageries he presented. Amin Rihani, for instance, one of Lebanon's early twentieth-century exponents of Arabism, could not resist the profound humanism of Corm's brand of Lebanese nationalism. Reading La Montagne Inspirée, Rihani wrote in 1934, one cannot help loving and identifying with Corm and his Phoenician Lebanon - even though Rihani would remain dubious as to whether or not the Phoenicians were truly worthy of Corm's love and adulation. ${ }^{26}$ "You are a lover of the human race," wrote Rihani in praise of his friend and philosophical adversary,

your heart bears within it oceans of affection, and your soul shines like bright sunlight of affection. You abscond both Frenchmen and Arabs, but you regale us with canticles emanating from the depths of your heart and soul, singing with devotion your boundless love for the peoples of your land. ${ }^{27}$

Still Rihani was at a loss to explain Corm's enthusiasm for the vanished Phoenicians while remaining lukewarm vis-à-vis the "living Arabs." Yet he could not help admitting that Lebanon was well deserving of Corm's love, dubbing The Hallowed Mountain the "Phoenicians' Song of Songs," writing that:

Lebanon and Charles Corm are a single inseparable moral and spiritual unit. Corm's unbounded love for Lebanon is incarnate in Lebanon's Cedars and Mountains, and in turn Lebanon's Cedars and Mountains willingly prostrate and melt before him, rendering themselves incense and emanations of light to be offered at his exalted national altar. [...] I read Corm's Hallowed Mountain and I feel as if transported from one festival of light to the next, from one orchard to the next, and from one raging volcano to the next; yet I remain firmly planted on Lebanese soil. ${ }^{28}$

25 Eliahu Epstein, "Lebanese Renaissance: La Montagne Inspirée by Charles Corm," Palestine Post, Jerusalem, February 24, 1935.

26 Amin Rihani, "Jabal al-Tajallī" [The Mount of Transfiguration] (Beirut: Al-Maarad, Special Issue, Number 38, July 4, 1934), 9.

27 Rihani, "Jabal al-Tajallī," 9.

28 Rihani, "Jabal al-Tajallī," 9. 
Even Khalil Takieddine (1906-1987), another Lebanese Arabist, confessed his sheer inability to resist the charisma, energy, and affection that Corm's work - and his person - exuded. Even for one committed to Lebanon's Arab identity as Takieddine had been, the lure and temptation of Phoenicianism were rendered exquisite, irresistible, and profoundly compelling through the magic flowing from Charles Corm's literary work. Khalil Takieddine admits to not being a fan of "national literature"; yet Corm's poetry, he stressed, commanded our attention because it broke free from the constraints of time and space and persons, and "it soared high above and beyond Lebanon, to heights far removed from narrow nationalism and into a most capacious universalism."29 Corm's work is universal and humanist in the true sense of the terms, wrote Takieddine, and it is the outcome of Corm's own spacious, universalist, vigorously and profoundly humanist formation; "a fine, delicious culture that eludes a good many of our company of literati in Lebanon today."30 And whereas Amin Rihani's Arabist leanings compelled him to criticize Corm's use of French instead of Arabic, Khalil Takieddine merely wished Corm had written in Arabic, "if only to show those so-called Arabic-language poets of our times - who in reality are scribblers and poseurs and cheap wordsmiths - how true poetry makes the heart flutter, how it makes the eye yearn for the sublime, and how its music lets loose one's feelings and stirs the emotions." ${ }^{31}$

In sum, La Montagne Inspirée was a stirring and exhilarating poem both to those who knew Charles Corm personally, and those who did not; to Lebanese who were invested in and sensitive to Corm's themes, and to foreigners who were not. To the Lebanese, La Montagne Inspirée was a veritable epopée. the stuff of legends, evoking in living poetic form all the hopes, the emotions, the disappointments, and the yearnings and memories of a people. Indeed, if there were such a thing as a repository in book-form for the spirit of a nation, Charles Corm's La Montagne Inspirée-had to be it; "a kaleidoscope of emotions," wrote Albert Naccache, "wonderfully depicted; a book that bewilders at first, then grabs hold of your heart, parading before you cavalcades of the most diverse of centuries and the most contradictory of events, where Lebanon is restituted in all its glory and splendour."32 Charles Corm is sometimes "too realistic" in his depiction of historical events, often "too brassy" in formulating his thoughts and his imageries, "yet he remains an idealist to a fault, supremely principled";

29 Khalil Takieddine, "al-Jabal al-Mulham wa-al-Adab al-Ālamī" [the Hallowed Mountain and Universal Literature] (Beirut: al-Ma'rad, Special Issue, Number 38, July 4, 1934), 25.

$30 \quad$ Ibid., 25 .

31 Ibid.

32 Albert Naccache, L'Orient, Beirut, January 14, 1934. 
an incarnation and confirmation of all that is great and graceful in Lebanon. ${ }^{33}$ The brassiness of Corm's poem can perhaps be summarized in the three simple words that he casually throws out at the beginning of each cycle: Traduit du Libanais or "translated from the Lebanese language." Therefore, while wielding all the languages of mankind, often with the intimacy of natives - as in the case with French - the Lebanese still breathed, clasped, sensed, and spoke a unique Lebanese language. And so ends Corm's "symphonic epopée" with the discloser that "even these sweet words, / Stolen from France's lips, / With impassioned affection / Quivering in my heart, / Still taste on my lips, / Where my smiling sorrow sits, / Still taste of a Lebanese kiss."

\section{Conclusions}

The work of francophone Lebanese novelist and member of the Académie Française Amin Maalouf (b. 1949) beautifully summarizes (and pays tribute to) the cultural humanism and the diverse polyglot cosmopolitanism promoted by the Young Phoenicians. Indeed, Amin Maalouf's personal trajectory, and even his literary characters, often read like ideas and ideals drawn from the Lebanon of Charles Corm and the Young Phoenicians. Maalouf even brought elements of this, his supremely Lebanese experience, to the acceptance speech he delivered at his induction into the Académie Française in June 2012. Sitting on the Académie's Chair number twenty-nine - a perch once occupied by Ernest Renan (1823-1892), a hero of sorts to the Young Phoenicians - Maalouf pledged to bring to the legacy of this venerable French institution all that he had inherited from the land of his birth; his origins, his languages, his accent, his convictions, his doubts, and more than anything else perhaps, his dreams of humanist harmony, progress, and coexistence among contradictions and opposites. $^{34}$

Even the engravings on Maalouf's ceremonial sword illustrate "Phoenicianist" ideals and the idea of contact and linguistic-intellectual intercourse between civilizations: on one side of the sword were featured an image of Marianne (symbolizing the French Revolution) grazing a Cedar of Lebanon, along with an engraving depicting the archetypal Phoenician princess, Europa, her abduction by an oxen image of the Greek god Zeus, and her establishment on the

33 Naccache, L'Orient.

34 See Amin Maalouf, "Discours de réception et réponse de M. Jean-Christophe Rufin; Réception de M. Amin Maalouf" (Paris: Académie française, June 14, 2012), http://www .academie-francaise.fr/discours-de-reception-de-amin-maalouf. 
continent that would come to carry her name. On the other side of the ceremonial sword were etched the names of Maalouf's wife and three sons, along with two words, "exile" and "identity," written in Arabic letters. ${ }^{35}$

And so, Amin Maalouf's Académicien's themes (or dreams) are found to be not all that different from those advanced by his Young Phoenicians elders; the images of Zeus and Europa are a symbol of the millennial tradition of contacts and cultural intercourse between Phoenicia and indeed the East as a whole on the one hand (a notion illustrated by the princess Europa whose name she would bequeath to a continent and a culture), and the West as illustrated by the god Zeus on the other.

"This inflection that you hear" in my Lebanese rendition of the French language, began Maalouf's speech to the Académie, is an accent that precious few ever hear any more in our France of today; it is certainly not the mode of speech in the confines of this bastion of French language and literature, the Académie Française. ${ }^{36}$ Yet, asserted Maalouf, the "rolled ' $\mathrm{R}$ " of his Lebanese-inflected French language had been the norm of all Frenchmen of times past: from the greats of seventeenth century French literature like La Bruyère and Racine, to sixteenth-century precursors such as Rabelais and Ronsard, to the very kings of France and the founder of the Académie himself, the Cardinal de Richelieu (ca. 1635), all of France once spoke with rolled "Rs." Therefore, Malouf claims:

This rolled " $r$ " is not coming to you from Lebanon; it is simply coming back from there. My [Lebanese] ancestors did not invent it. They simply preserved it in the form in which they had received it from the mouths of your forebears, [...] many of whom - like Volney, Lamartine, and Barrès, to name only those - visited us often. [...] Let me pause for a moment and reflect briefly on one of those Lebanese at heart: Ernest Renan. Renan wrote his "Life of Jesus" in six weeks, in one sitting, at the foot of Mount-Lebanon. He had wished to be buried there, in Lebanon, near the coastal city of Byblos, in the vault where his beloved sister, Henriette, lay. [...] People often attribute the ascendancy and influence of the French language to France's colonial era. That may be the case in many places in the world! Not so in Lebanon. [... Our] romance is centuries old. The love story between the homeland of my birth and my adoptive country owes

35 "Amin Maalouf entre à l'Académie Française" in Le Monde, June 14, 2012, https://www .lemonde.fr/livres/article/2012/06/14/amin-maalouf-entre-a-l-academie-francaise_ 1718861_326o.html.

36 Maalouf, "Discours de réception". 
little to military conquest and much to the skilled diplomacy of King François I [...] who took special interest in the peoples of the Levant. ${ }^{37}$

Therefore, this Franco-Lebanese romance, claimed Maalouf, is ongoing and has been evolving since at least the thirteenth century. Yet, he noted, its true origins were much more removed in time, going back to an era when gods and men walked the earth alongside one another, and when the god Zeus, assuming the likeness of an ox, seduced a Phoenician maiden named Europa and made off with her from the Lebanese coasts of Tyre and Sidon to the continent that would become her own, bearing her name. ${ }^{38}$ Later, Europa's brother Cadmus, on his quest to find his sister and bring her home, transmitted to the Greeks the Phoenician alphabet, precipitating the development of the Greek alphabet (and with it Greek knowledge), and all that would follow in manner of human accomplishments. This was mythology of course, admitted Maalouf, but "mythology tells us stories that History itself might have forgotten; and this myth of the abduction of Europa in particular, is a codified acknowledgement of a debt - the cultural debt owed by ancient Greece to ancient Phoenicia."39

Amin Maalouf concluded the "Phoenician" segment of his speech by borrowing a description of Cadmus from the man that he was replacing on the Académie's Chair number twenty-nine - cultural anthropologist Claude Lévy-Strauss - who portrayed the Phoenician archetype as "the civilizer [of Europe]; [the man who] had sown the dragon's teeth [...] upon this land, scorched and burnt as it were by a monster's breath, [where] we awaited [and witnessed] the sprouting of mankind."40

I would like to close with a quote from Amin Maalouf's historical novel Leo Africanus, because I think the protagonist [Leo Africanus] serves as a model for Lebanon and the Middle East as a whole (past, and hopefully future), but also because Leo encapsulates the archetypal Young Phoenician of Charles Corm's generation. Maalouf's Leo saw his native land as a richly textured human, cultural, and historical space, composed of Arabs and Muslims (and their artefacts) to be sure, but teeming with non-Arabs and non-Muslims (and their artefacts) as well; a space with topologies, climates, histories, languages, geographies, and cultural monuments favourable to diverse human compositions, synthesizing centuries of intellectual, linguistic and cultural traffic. As one may discern, Amin Maalouf's Leo Africanus may indeed be seen as an

37 Ibid.

38 Ibid.

39 Ibid.

$40 \quad$ Claude Lévi-Strauss, Tristes Tropiques (Paris: Plon, 1995), 141. 
anthropomorphic Lebanon, a Lebanon of the Young Phoenicians certainly, but also a microcosm of the rest of the Levantine Middle East. This is how Leo introduced himself to his readers in Maalouf's narrative:

I, Hassan, the son of Muhammad the scale master; I, Jean-Léon de Médicis, circumcised at the hands of a barber and baptized at the hands of a Pope, I am now called the African. But I am not from Africa, nor from Europe, nor from Arabia. I am also called the "Granadan," the "Fezzi," the "Zayyati," but I come from no country, from no city, from no tribe. I am the son of the road; a wayfarer. My homeland is the caravan; my life the most spectacular of pathways, the most riveting of travels ... - My wrists have rubbed, in turn, against the caresses of silk, the chafing of wool, the gold of princes, and the chains of slaves. My fingers have parted a thousand veils, my lips have made a thousand virgins blush, and my eyes have seen cities die and empires collapse. From my mouth you will hear Arabic, Turkish, Castilian, Berber, Hebrew, Latin, and Italian vulgates, because all tongues and all prayers belong to me. But I belong to none. ${ }^{41}$

This is the Lebanon of the Young Phoenicians (and through it, the rest of the Middle East), a diverse universe that many of its children are still striving to preserve. This is ultimately the future of the Middle East; a recasting of identity and language and places of memory in a space that is anything but the monolith that we have come to perceive in these past one hundred years of encounters, discoveries, analyses and interpretations. Some may opt to forget history, or rewrite history, or even suppress and falsify history for political purposes. But "History is the collective memory, the guiding experience of human society," wrote Bernard Lewis, and the Middle East, its motley crew of peoples, traditions, and cultures "still badly need [the] guidance" of history as both an art and a science; a noble human and humanist endeavour. ${ }^{42}$ It is from this premise that muffled and concealed Middle Eastern voices - their languages and their stories - ought to be excavated, uncovered, restored, and recovered.

41 Amin Maalouf, Léon l'Africain (Paris: Livres de Poche, 1987), 2. It is worth noting that Leo Africanus was a real life personality; his name was Hassan al-Wazzan, Leo the African, a sixteenth century Andalusian Amazigh Muslim diplomat and author, best known for his book Descrittione dell' Africa (Description of Africa); he was born a Muslim and raised as a Christian in the court of Ferdinand and Isabella, and was converted to Catholicism by Pope Leo $\mathrm{x}$, who gave him his name.

42 Bernard Lewis, From Babel to Dragomans; Interpreting the Middle East (Oxford and New York: Oxford University Press, 2004), 395. 


\section{Bibliography}

Akl, Saïd. "Netruk Ba’a l-Arabi" [Enough Already with the Arabic Language]. Lebnan IX,433 (August 10, 1984).

Antar, Ornella. "Depuis des millénaires le peuple libanais n'a pas bougé d'un iota." L'Orient Le Jour (July 29, 2017). https://www.lorientlejour.com/article/1064754/ -depuis-des-millenaires-le-peuple-libanais-na-pas-bouge-dun-iota-.html.

Archache, Jeanne. "La Bourse Egyptienne." Extraits de la Critique, Alexandria (February 8, 1935).

Boustany, Fouad Ephrem. "La trace du Phénicien Ugaritique dans le parler libanais." Opera Minora; Studia Libanica 69-87. Beirut: Editions ad-da'irah, 1986.

Charrier. "Domestic and Foreign Research." Extraits de la Critique, New York (November 25, 1934).

Chiha, Michel. Le Liban d'Aujourd'hui (1942). Beyrouth: Editions du Trident, 1961.

Chiha, Michel. Visage et presence du Liban. Beyrouth: Le Cénacle Libanais, 1984 (2nd edition).

Corm, Charles. "Déclaration de M. Ch. Corm." In Les Principes d'un Humanisme Méditerranéen (Monaco, November 1935).

Corm, Charles. La Montagne Inspirée. Beirut: Éditions de la Revue Phénicienne, 1934/1987.

Deeb, Marius. Syria, Iran, and Hezbollah: The Unholy Alliance and its War on Lebanon. Stanford, California: The Hoover Institution Press, 2013.

E.M. “La Revue du Liban et de l'Orient Méditerranéen." Extraits de la Critique, Paris (February 1934). Beirut: Éditions de la Revue Phénicienne, 1935.

Epstein, Eliahu. "Lebanese Renaissance: La Montagne Inspirée by Charles Corm." Palestine Post, Jerusalem (February 24 1935).

Kedourie, Elie. "Not So Grand Illusions." New York Review of Books 9,9 (Nov. 23, 1967).

Lévi-Strauss, Claude. Tristes Tropiques. Paris: Plon, 1995.

Lewis, Bernard. From Babel to Dragomans; Interpreting the Middle East. Oxford and New York: Oxford University Press, 2004.

Maalouf, Amin. Léon l'Africain. Paris: Livres de Poche, 1987.

Maalouf, Amin. "Discours de réception et réponse de M. Jean-Christophe Rufin; Réception de M. Amin Maalouf." Paris: Académie française, June 14, 2012. http:// www.academie-francaise.fr/discours-de-reception-de-amin-maalouf.

Naccache, Albert. L'Orient (January 14, 1934).

Rihani, Amin. "Jabal al-Tajallī." [The Mount of Transfiguration] Al-Ma'rad (special issue) 38 (July 4, 1934).

Salameh, Franck. Language Memory and Identity in the Middle East; The Case for Lebanon. Lanham, MD: Lexington Books, 2010. 
Takieddine, Khalil. "al-Jabal al-Mulham wa-al-Adab al-Ālamī." [the Hallowed Mountain and Universal Literature]. al-Ma'rad (special issue) 38 (July 4, 1934).

Tyane, Élie. Lumière sur la Montagne. Beirut: Éditions de la Revue Phénicienne, 1935.

Zalloua, Pierre A. et al., "Identifying Genetic Traces of Historical Expansions: Phoenician Footprints in the Mediterranean." American Journal of Human Genetics 83,5 (2008). https://www.ncbi.nlm.nih.gov/pmc/articles/PMC2668035/. 